\title{
Aquatic ecosystem services of reservoirs in semi-arid areas: sustainability and reservoir management
}

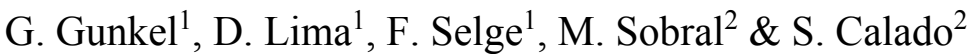 \\ ${ }^{1}$ Berlin University of Technology, Germany \\ ${ }^{2}$ Universidade Federal de Pernambuco, Brazil
}

\begin{abstract}
The multiple use of reservoirs is widely accepted, but there are frequent conflicts between water users based on ecological, economic and sociological concerns. The promotion of aquatic ecosystem services is a successful approach to advanced reservoir management. The main aquatic ecosystem services are goods and human benefits such as clean water and hydropower. The sustainability of aquatic ecosystem services must be the aim of a reservoir management plan, and hence adequate water quality and predominantly mesotrophic conditions are necessary. However, eutrophication processes are advanced in many tropical reservoirs, and re-oligotrophication is needed, as has been successfully implemented in temperate lakes. The eutrophication processes and re-oligotrophication potential of tropical reservoirs are significantly different from temperate ecosystems. Studies to quantify the impact of ecosystem services were conducted on the Itaparica reservoir, São Francisco River, Brazil, which is located in a semi-arid area. The main disturbance to tropical reservoirs is the change in water level due to hydropower operational conditions. Desiccated areas on the lakeshore have a high potential for nutrient release by sediment mineralization. An increase in the water level promotes the growth of some pioneer plants, such as the water pest, Egeria densa. Intensive net cage aquaculture can lead to an overcharge of the reservoir, and therefore the carrying capacity should be considered. Furthermore, sediment management and the abstraction and re-use for soil amendment has to be managed. The multiple water uses and sustainability of aquatic ecosystem services must be the aim of any reservoir management plan, and the eutrophic level is a key factor due to its impact on water quality.

Keywords: ecosystem service, reservoir, semi-arid area, water management, eutrophication.
\end{abstract}




\section{Introduction}

Human health and quality of life is limited by access to clean and sufficient water throughout the year, with many regions characterized by water scarcity and seasonal droughts, as well as the contamination of water due to insufficient wastewater treatment. Most water supply problems exist in semi-arid and arid zones, where a great effort has been made to increase the available water, mainly by decentralised water harvesting (e.g. by cisterns, small ponds, subsurface dams and small dikes) and the damming of rivers.

Large reservoirs are very common in the tropical zone, with about 29,000 worldwide (69\% of the global total), and about 700 new reservoirs constructed every year [1]. Tropical reservoirs are very important for hydropower, and flow regulation and inundation control because rainfall tends to occurs intensively over a short period.

Due to water scarcity the multiple use of reservoirs is common, with the main uses being flood control, hydropower and water abstraction (drinking water, watering farm animals, irrigation, and the increasingly significant transposition of water to other water-sheds) [2]. Further uses of reservoirs include aquatic biodiversity, recreation and fishing, which are often regarded as secondary uses. Conflicts between water uses and users do not consider the complexity of the ecological processes in tropical reservoirs. The linkage of the aquatic ecosystem with the watershed, and the effects of climate change on water quantity and quality are also very significant. The concept of aquatic ecosystem services (ESS, Fig. 1) provides a better approach to managing the human benefits from reservoirs, and promoting sustainable use through effective protection and management.

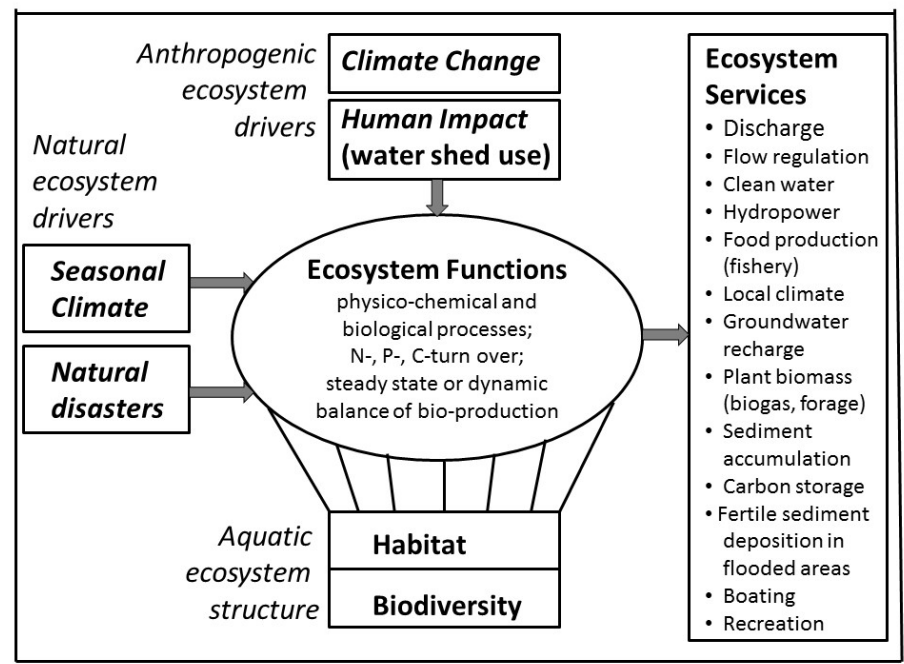

Figure 1: Linkage of reservoir ecosystem functions and services with the ecosystem structure and the main drivers of the ecosystem. 
There is not yet a consensus on the definition of ESS, and ecosystem processes, function and goods must be distinguished [3,4]. It was reported in a literature review that most studies $(43 \%)$ consider ecosystem processes and functions as ESS, while $22 \%$ consider ecosystem goods to be ESS, and the rest prefer structural components, human uses and securities [4]. The European Environmental Agency favours a clear distinction between the final ESS, goods or products and benefits [5]. Boyd and Banzhaf [6] provide the following useful definition of ESS: "Final ecosystem services are components of nature, directly enjoyed, consumed or used to yield human well-being. Many, if not most, components and functions of an ecosystem are intermediate products in that they are necessary to the production of services but are not services themselves." From an ecological approach, ecosystem processes (e.g. C assimilation) build up the ecosystem function (e.g. self-purification), which leads to the ecosystem providing good 'clean water'. ESS should be restricted to goods and direct human benefits as end products. Processes, components and functions of an ecosystem are intermediate products that may be necessary, but are not services themselves. This approach also leads to a better economic evaluation of ESS.

\section{Study area and methods}

The limnology of tropical reservoirs was studied in the São Francisco river region of Northeast Brazil, with a focus on the Itaparica reservoir, which is located in the semi-arid area of Brazil. The São Francisco River is one of Brazil's main rivers, with a water basin of $640,000 \mathrm{~km}^{3}$. It stretches from Minas Gerais in the rainy southwest of Brazil to the dry zone of Northeast Brazil, with a length of $3,160 \mathrm{~km}$. The middle course of the São Francisco River has an annual precipitation of about $430 \mathrm{~mm}$ year $^{-1}$ and an annual evaporation rate of 2,386 mm [7]. The rainy period extends from February to April, with the driest period from June to December. The annual temperature averages around $26^{\circ} \mathrm{C}$.

Eight reservoirs have been constructed in the São Francisco River, including Itaparica. The Itaparica reservoir is in the middle course of the river, and is located in a semi-arid region, $290 \mathrm{~km}$ from the Atlantic Ocean (Fig. 2). The Itaparica dam was finished in 1988, and was built for hydroelectric power generation $(1,480$ $\mathrm{MW}$ ), while also providing water storage. The reservoir has a regulated inflow of $2,060 \mathrm{~m}^{3} / \mathrm{sec}$, a length of $149 \mathrm{~km}$, a surface area of $828 \mathrm{~km}^{2}$ and a sub water basin of $93,040 \mathrm{~km}^{2}$. The maximum depth is $101 \mathrm{~m}$ (mean depth $\left.=13 \mathrm{~m}\right)$, and the reservoir's capacity is $10.7 \times 10^{9} \mathrm{~m}^{3}$.

The damming of the São Francisco River had several serious effects on ecosystem function [8, 9], and a new economic system based on irrigation agriculture had to be developed for nearly 40,000 relocated people.

Water is abstracted mainly for irrigation (50.5\% of the total usage), but other water uses are of increasing significance, including the abstraction of water for aquaculture (pond culture at the margins) and net cage culturing in the reservoir, as well as the transport of water to other areas in Northeast Brazil. 




Figure 2: The São Francisco River and Itaparica reservoir in Brazil.

For the last 10 years, regular monitoring of water quality has been conducted by CHSEF (Companhia Hidrielectrico do São Francisco). Limnological and socioeconomic studies have also been conducted $[8,10]$. Since 2012, the interspecific binational research program INNOVATE (Interplay among multiple uses of water reservoirs via inNOVative coupling of substance cycles in Aquatic and Terrestrial Ecosystems) has been ongoing [11]. To study the water, sediment, plankton and macrophytes, standard limnological methods were used [12].

\section{Results and discussion}

\subsection{Characteristics of tropical reservoirs}

Limnology has his historical sources in some European countries and is mainly applied in the northern temperate hemisphere, with most research conducted under climatic conditions with strong seasonal effects (summer and winter), moderate temperatures $\left(<22^{\circ} \mathrm{C}\right)$ and an even distribution of precipitation throughout the year.

The focus of our research was the hot and dry area in Brazil that is characterized by the 'caatinga' biome, a semi-arid area with a tropical dry forest. The main differences between reservoirs in semi-arid zones compared to temperate conditions are:

- high radiation input with year-long bio-production,

- high UV input; however, this is compensated for by well-known UV protection mechanisms of organisms,

- $\quad$ high and nearly constant water temperatures of $25^{\circ} \mathrm{C}-35^{\circ} \mathrm{C}$,

- a wet and dry season, with short heavy rainfall of a few hours within the rainy period,

- $\quad$ streams with intermittent flow rates and a large variation in the water discharge,

- intensive water level changes due to the seasonality of rainfall, with desiccation of large lakeshore areas, 
- $\quad$ high evapotranspiration rates, soil moisture may reach the surface layer via capillary upwelling and lead to soil salinization, with damage to the riverine vegetation,

- thermal stratification with a small temperature difference and the frequent occurrence of polymictic mixing or atelomixis,

- $\quad$ reduced input of $\mathrm{N}$ from the watershed as a consequence of intensive and year-round denitrification in soils,

- dominance and mass development of cyanobacteria,

- the occurrence and mass development of invasive species, e.g. neophytes (Eichhornia, Pistia) and cyanobacteria (e.g. Cylindospermopsis raciborskii),

- the introduction of economic species (Eucalyptus, trout, carp and tilapia), with an associated impact on natural fauna and flora.

Thus, the characteristics of reservoirs in semi-arid areas differ significantly from those in temperate conditions, and the analysis of tropical aquatic ecosystems requires further research [13].

\subsection{Aquatic ecosystem services}

The ESS concept is a good approach for reservoir management, because it clearly highlights the interaction of socio-economic activities by the inhabitants of the watershed and the ecological reaction of soils, vegetation and water bodies [14]. The application of the ESS concept to reservoir management includes (1) the identification of the ESS, (2) measuring, quantifying and valuing the ESS, (3) the development of protection and restoration strategies for reservoirs, and (4) the development of management options and implementing strategies for reservoirs.

Some of the more significant ESS are:

- $\quad$ provision of water for hydropower, flow regulation, cooling water and downstream flow,

- $\quad$ provision of clean water (drinking water, watering farm animals, irrigation and water transfer),

- $\quad$ regulation of the local climate (e.g. cooling effects, moisture provision),

- food production (fishery, water birds and crayfish), although a good quality (i.e. free of residues, such as xenobiotics or cyanotoxins) must be assured,

- $\quad$ plant growth, e.g. used for biogas,

- deposition of suspended load in flooded areas (amendment of soils),

- accumulation of sediments and their re-use for soil amendment,

- carbon storage, mainly by organic rich sediments,

- recreation and aesthetic value,

- $\quad$ shipping,

- bank filtration for drinking water treatment,

- ground water recharge.

The application of the ESS model to reservoirs must consider the downstream ecosystem, which means the outflow of the reservoir also has to be regarded as an ESS, and a minimum discharge must be defined due to the downstream ecosystem structure and services.

Multiple and sustainable uses of reservoir ESS are only possible with good water management and the protection or rehabilitation of ecosystem functions. To 
achieve this significant consideration has to be given to ecosystem processes such as:

- primary production and eutrophication processes by $\mathrm{N}$ and $\mathrm{P}$,

- mineralization of organic matter (particulate organic matter (POM), dissolved organic matter (DOM)) as an input from the watershed, also leading to eutrophication,

- $\quad$ self-purification as the sum of different processes that regulate water quality, - erosion in the watershed and the accumulation of sediments in the reservoir, - secondary production, e.g. by fish, with artisanal fishery and aquaculture.

The main targets of any reservoir management plan are eutrophication control, limiting the dominance of cyanobacteria, development of an adapted land use to minimize export rates and limiting contamination by xenobiotics. In Table 1, reservoir ESS are listed with an initial estimation and evaluation of their economic significance.

\subsection{Reservoir management}

\subsubsection{Water quality guidelines for trophic parameters}

In many cases, tropical reservoirs have poor water quality. The main reasons for this are the natural process of trophic upsurge [15], the absence of or the inefficiency of sewage collection and wastewater treatment, and the high potential for eutrophication because of the high temperature and year-round bio-production.

However, the Itaparica reservoir is an input-output system, with a high inflow rate. Typically for a reservoir that is used for hydropower generation, there is increased sedimentation due to the damming. Accumulated sediments are enriched with organic matter and the decreased redox potential will mobilize $\mathrm{P}$ by redoxchemical processes. Nutrient rich inundated soils and the vegetation remaining after damming up promote this process.

In Brazil, water quality guidelines are given by the Conselho Nacional do Meio Ambiente (CONAMA) water classification system. Water for human consumption has a guideline value of $30 \mu \mathrm{g} \mathrm{L}^{-1}$ for chlorophyll a, 50,000 cells $\mathrm{mL}^{-1}$ for cyanobacteria, and $30 \mu \mathrm{g} \mathrm{L}^{-1}$ for P [16]. Cyanotoxins are limited to $1.0 \mu \mathrm{g} \mathrm{L}^{-1}$ (microcystin, cylindrospermopsin) resp. and $3.0 \mu \mathrm{g} \mathrm{L}^{-1}$ (saxitoxin) [17].

Eutrophication control in tropical reservoirs is based on the $\mathrm{P}$ use efficiency, using the correlation of algae chlorophyll (as an indicator of biomass) with the $\mathrm{P}_{\text {tot }}$ concentration. The critical mean $\mathrm{Chl}$ a concentration is $5 \mu \mathrm{g} \mathrm{L}^{-1} \mathrm{Chl}$ a, which corresponds to mesotrophic conditions. The OECD [18] suggested a value of $9 \mathrm{~g}$ $\mathrm{L}^{-1} \mathrm{P}_{\text {tot }}$ was sufficient for northern hemisphere lakes, while the CEPIS (Centro Panamericano de ingenieria sanitaria y ciencias del ambiente) correlation for South American lakes and reservoirs gave a value of $31 \mathrm{mg} \mathrm{L}^{-1} \mathrm{P}_{\text {tot }}$ [19]. For tropical lakes and reservoirs, Huszar et al. [20] derived a value of $20 \mu \mathrm{g} \mathrm{L}^{-1} \mathrm{P}_{\text {tot }}$. Phillips et al. [21] determined a value of $12 \mu \mathrm{g} \mathrm{L}{ }^{-1} \mathrm{P}_{\text {tot }}$ for low to moderate alkaline and shallow lakes, and Gunkel et al. [9] derived a value of $9 \mu \mathrm{g} \mathrm{L}{ }^{-1} \mathrm{P}_{\text {tot }}$ for the Itaparica reservoir.

In addition to evaluating the $\mathrm{P}$ concentration, the abundance and diversity of algae can be used as a parameter to indicate water quality, e.g. the Australian 
Table 1: Reservoir ecosystem services and their economic significance in the Itaparica reservoir.

\begin{tabular}{|c|c|c|c|}
\hline Final goods & $\begin{array}{c}\text { Minimum } \\
\text { water quality }\end{array}$ & Human benefits & $\begin{array}{l}\text { Economic quantity } \\
\text { and value per year }\end{array}$ \\
\hline \multirow[b]{2}{*}{ Water } & $\begin{array}{l}\text { meso-to } \\
\text { eutrophic }\end{array}$ & Hydropower, 1,480 MW & $320-600 \times 10^{6}$ US\$ \\
\hline & none & $\begin{array}{l}\text { Mitigation of droughts and } \\
\text { floods, well-being of } 50,000 \\
\text { people }\end{array}$ & \\
\hline \multirow{4}{*}{ Clean water } & oligotrophic & $\begin{array}{c}\text { Drinking water supply, } \\
45,000 \text { people }\end{array}$ & $\begin{array}{l}3.3 \times 10^{6} \mathrm{~m}^{3} \\
3.6 \times 10^{6} \mathrm{US} \$\end{array}$ \\
\hline & mesotrophic & $\begin{array}{l}\text { Watering farm animals, } 5,000 \\
\text { animals }\end{array}$ & $0.1 \times 10^{6} \mathrm{US} \$$ \\
\hline & mesotrophic & $\begin{array}{l}\text { Irrigation water, } 4,700 \text { ha, } 0.6 \\
\qquad \mathrm{~L} \mathrm{sec} \mathrm{ha}^{-1}\end{array}$ & $\begin{array}{c}90 \times 10^{6} \mathrm{~m}^{3} \\
0.9 \times 10^{6} \mathrm{US} \$\end{array}$ \\
\hline & oligotrophic & Aquaculture water supply & $\begin{array}{c}20,000 \mathrm{t} \mathrm{y}^{-1} \text { fish } \\
35 \times 10^{6} \text { US\$ }\end{array}$ \\
\hline $\begin{array}{l}\text { Downstream } \\
\text { discharge }\end{array}$ & $\begin{array}{l}\text { depending on } \\
\text { downstream } \\
\text { ESS }\end{array}$ & $\begin{array}{c}\text { Downstream ecosystem } \\
\text { services, soil amelioration, } \\
\text { blockage of river delta salt } \\
\text { intrusion }\end{array}$ & $1200 \mathrm{~m}^{3} \mathrm{sec}^{-1}$ \\
\hline $\begin{array}{l}\text { Regulation of } \\
\text { local climate }\end{array}$ & none & Well-being of 50,000 people & \\
\hline $\begin{array}{c}\text { Food } \\
\text { production }\end{array}$ & mesotrophic & $\begin{array}{c}\text { Artisanal fishery, } 1000 \\
\text { fishermen }\end{array}$ & $14 \times 10^{6} \mathrm{US} \$$ \\
\hline $\begin{array}{c}\text { Production of } \\
\text { macrophytes }\end{array}$ & mesotrophic & Biogas production & Not yet used \\
\hline $\begin{array}{l}\text { Carbon } \\
\text { assimilation by } \\
\text { biomass and } \\
\text { sediments }\end{array}$ & mesotrophic & Mitigation of climate change & $\begin{array}{c}80,000 \mathrm{t} \mathrm{CO}_{2} \\
1.2 \times 10^{6} \mathrm{US} \$\end{array}$ \\
\hline $\begin{array}{l}\text { Accumulation } \\
\text { of sediments }\end{array}$ & mesotrophic & $\begin{array}{l}\text { Amendment of soils (1) in } \\
\text { areas inundated by flooding, } \\
\text { (2) by re-use for soil }\end{array}$ & \\
\hline $\begin{array}{l}\text { Recreation and } \\
\text { aesthetic value }\end{array}$ & mesotrophic & Well-being of 10,000 people & \\
\hline Boating & & Transport & 1 ferry boat \\
\hline $\begin{array}{l}\text { Groundwater } \\
\text { recharge }\end{array}$ & $\begin{array}{c}\text { oligo-to } \\
\text { mesotrophic }\end{array}$ & Drinking water supply & Not yet used \\
\hline Bank filtration & mesotrophic & Drinking water supply & Not yet done \\
\hline
\end{tabular}

Drinking Water Guidelines [22]. This guideline considers the role of the toxin producing cyanobacteria Microcystis aeruginosa and Cylindrospermopsis raciborskii, and provides guideline values of $1.3 \mu \mathrm{g}$ microcystin-LR and $1 \mu \mathrm{g} \mathrm{L}^{-1}$ cylindrospermopsin, which is given by a cell density of approximately 6500 cells $\mathrm{mL}^{-1}$ (Microcyctis aeruginosa) and 15,000 to 20,000 cell $\mathrm{mL}^{-1}$ (Cylindospermopsis raciborskii). 


\subsubsection{Eutrophication control}

Lake eutrophication control strategies are well established and provide the means for lake sanitation (i.e. management of the watershed) and lake restoration (i.e. in situ measurements). Reservoir management, with a focus on re-oligotrophication, is based on various restoration technologies, including strategies such as:

- $\quad$ adapted sediment management, with the goal of excavating nutrient rich sediments and deepening the reservoir, while the sediment should be used in agriculture for soil melioration,

- $\quad$ reducing water level changes caused by operational conditions,

- $\quad$ weed harvesting as nutrient output,

- development of a "green" aquaculture, limited by the carrying capacity of the reservoir.

Tropical reservoirs undergo rapid eutrophication, caused by the mobilization of nutrients from inundated area (soils, vegetation) and the trapping of suspended matter due to the increased water retention time in the dammed water body, which is referred to as trophic upsurge. Additionally, a so-called cultural eutrophication occurs due to the migration of people near the shore of the reservoir, and the development of infrastructure such as villages, small towns, agriculture and industry. Eutrophication of reservoirs occur within a few years or decades, which is much faster than in natural lakes [15].

The concept of re-oligotrophication to the level immediately after damming is a new approach to mitigate the trophic succession of a reservoir, and is supported by the water quality guidelines. The impact on water quality is apparent from the dominance of cyanobacteria and their production of cyanotoxine, the mass development of macrophytes, diurnal oxygen, and $\mathrm{pH}$ oscillations with lethal conditions for fauna [9].

One aspect of major importance is the limitation of algae production in tropical reservoirs. Many researchers have reported an $\mathrm{N}$ limitation in tropical areas, which is logical (e.g. high year-round denitrification in the watershed and the dominance of cyanobacteria), but some more recent studies have also reported a $\mathrm{P}$ limitation or an N-P co-limitation $[23,24]$. Therefore wastewater treatment is a primary task and is a very important part of any re-oligotrophication strategy. In Itaparica reservoir, P or N-P co-limitation occurs.

\subsubsection{Water level fluctuations}

In reservoirs, extensive water level changes occur due to operational conditions. Over the year the water level changes regularly by 4-5 $\mathrm{m}$ in Itaparica reservoir (Fig. 3), while other reservoirs experience water level changes $>10 \mathrm{~m}$. The main reason for this is the seasonality of rainfall and inflow rate, with more or less constant energy production, which means a decoupling of hydroelectric power generation and water availability.

With water level changes periodic desiccation of large shallow lake areas occurs, which in the case of Itaparica reservoir accounts for about $27 \%$ of the lake surface. The main consequences of this are:

- the regular breakdown of littoral fauna and flora, 


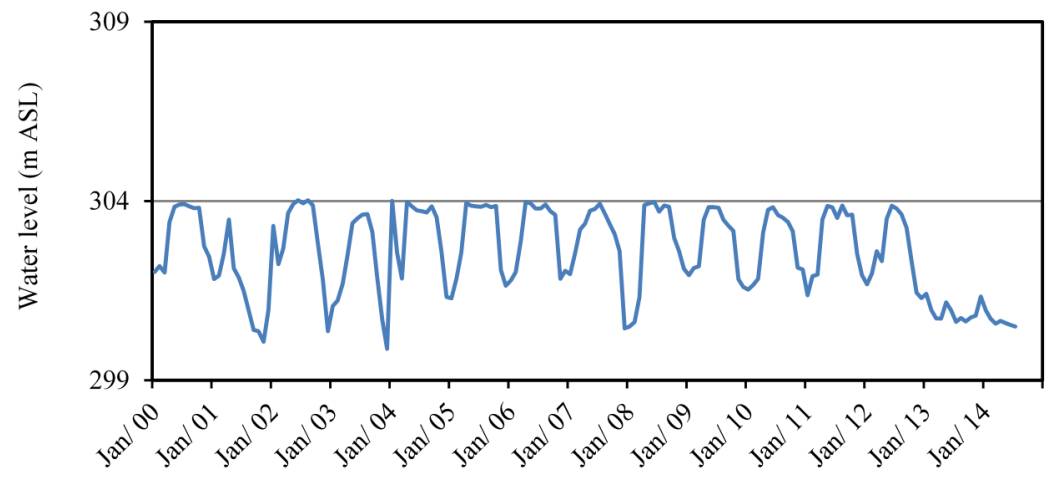

Figure 3: Water level fluctuations due to climatic and operational conditions in Itaparica reservoir during the 2013/2014 long-term drought period.

- reduced biodiversity of submerged and terrestrial fauna and flora in the lake margins,

- resuspension of deposited sediments by wind waves as the water level falls,

- a decrease in the stability of the thermal stratification of the reservoir at low water levels,

- mineralization of the desiccated sediments, with leaching of N, P and DOC after rewetting,

- during high water level, the development of fast growing filamentous algae or pioneer plants (e.g. Egeria densa). Plants with a reproduction period $>8$ months do not develop.

This large variation of the water level has severe effects on the reservoir ecosystem, due to (1) damage to the lakeshore ecotone and the retention function of the littoral vegetation strip, (2) eutrophication of the water body and (3) the promotion of fast growing submerged pioneer plants (such as Egeria densa) and filamentous algae.

Only few studies have investigated littoral desiccation. The long-term desiccation of littoral sediments is very significant for nutrient emissions because the introduction of gaseous oxygen into the sediment pore system damages the aquatic microbes and organisms and leads to the abiotic mineralization of organic material. After rewetting N, P and organic C are dissolved in water and washed out [25]. Sediment core experiments using long-term dried sediments from the lakeshore indicated a leaching of up to $75 \mathrm{mg} \mathrm{m}^{-2} \mathrm{P}_{\text {total dissolved }}$ after rewetting (Fig. 4). Eutrophication of Itaparica reservoir by the rewetting of desiccated lake areas is of significance and could damage the ecosystem service of providing "clean water". This effect takes place mainly in bays of the reservoir, due to the limited water exchange between main stream and bays [26].

The water level variations need to be reduced by an ecologically orientated reservoir management plan and should also be a criterion in the environmental assessment of new reservoirs. Hydropower cannot be seen as a constant and basic energy source, but is regulated by the availability of water. Therefore, both wet 


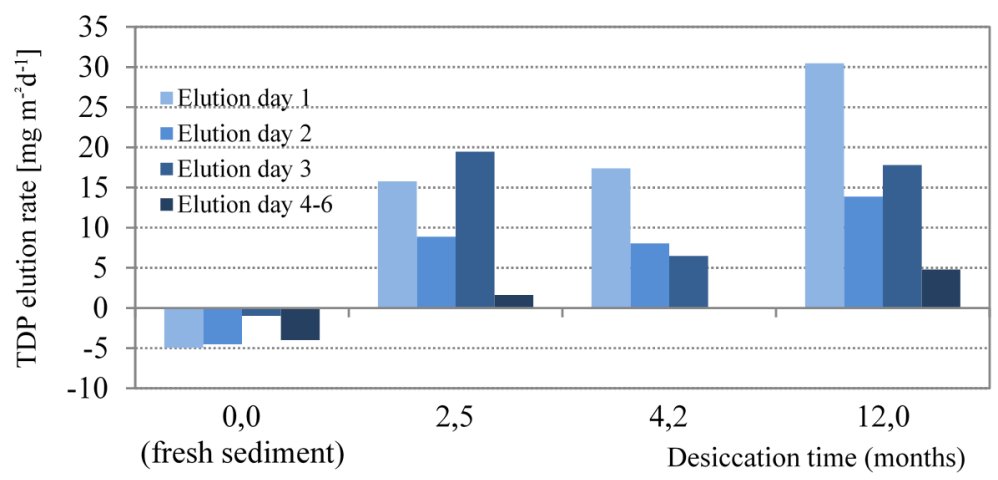

Figure 4: Elution experiments with lakeshore sediments from Itaparica reservoir (TDP $=$ total dissolved phosphorus).

and dry seasons, as well as periodic drought periods in excess of one-year, have to be considered in reservoir management. Energy production has to be strictly limited during the dry season, to guarantee the other ESS.

\subsubsection{Weed harvesting}

In many tropical reservoirs the development of a mass of aquatic plants occurs, leading to an impact on ESS, mainly by free floating plants like Eichhornia or Azolla, which can cover the whole lake surface, or by submerged plants such as Egeria densa, which has been named 'water pest'. In Itaparica reservoir Egeria densa is the most abundant specie, with stands growing several meters high (Fig. 5). Egeria densa is a pioneer plant that can develop a large biomass when environmental conditions such as the water level vary. The impact of Egeria densa on ESS includes:

- restrictions on fishing and boating,

- blockage of turbines,

- $\quad$ promotion of the water born disease, Schistosomaisis, because Egeria densa serves as a substratum for the snail, Biomphalaria, which is the host of Schistosoma,

- $\quad$ increased eutrophication with high primary production, increased $\mathrm{pH}$ and a lack of oxygen in deeper water layers and sediment.

There is a need for the regulation of Egeria densa biomass, but the control options are limited. Egeria densa is a pioneer plant that is fast growing, with a very high capacity to take up $\mathrm{CO}_{2}$ at low concentrations (C4-like mechanism). Both $\mathrm{N}$ and $\mathrm{P}$ are absorbed primarily from water, but to some extent also from sediment. Thus, the limitation of Egeria densa growth by nutrient availability is not successful. Propagation is vegetative, and therefore small fragments of the plant (e.g. cut by a boat propeller) will grow to become new plants. Chemical treatment with pesticides is strictly limited due to contamination issues and oxygen depletion after treatment. The biological limitation of Egeria densa by herbivores is not viable because of the high growth rate (up to $2 \mathrm{~cm}$ per day) and the lack of large herbivorous animals in the area. 


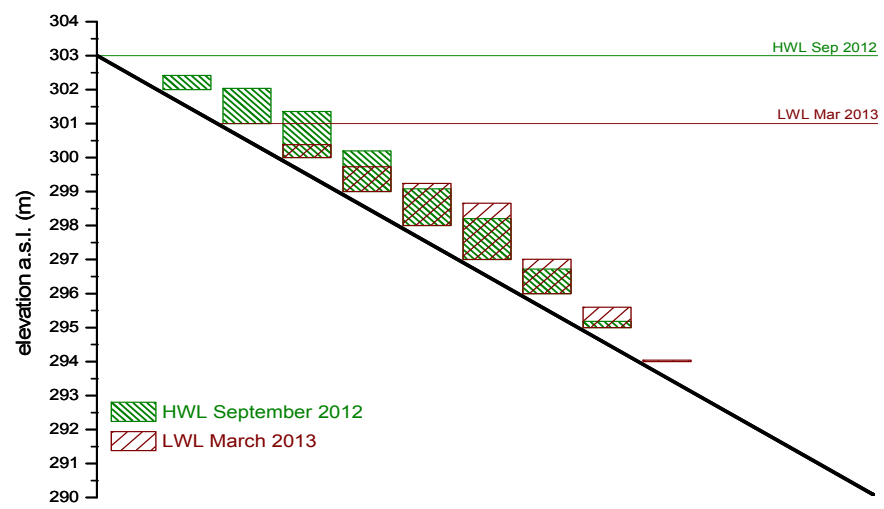

Figure 5: The occurrence of Egeria densa in Itaparica reservoir at different water depths during high and low water, and plant height as a vertical extension of the columns.

The use of the plants for animal feeding or soil amelioration is possible, but this is not very effective because of the high water content $(88 \%)$ and low nutritional value $\left(0.2 \% \mathrm{P}_{\text {dry weight }}\right)$. The underwater cutting of the macrophytes is very laborious and is difficult in deep water. It could leads to the propagation of the plants due to the loss of fragments. The cutting of large areas is very difficult as shown by studies in Brazil [27]. The harvester must be fixed with a steel line from one shore to the other to cut adjacent strips of vegetation, which is a technology developed for sediment abstraction. Egeria densa can be used for biogas production, but the energy yield is very low (about $55 \mathrm{~L} \mathrm{~kg}^{-1}$ wet weight, [28]). In general, the work expended in harvesting and transport reduces the economic value of Egeria densa, and no sustainable agricultural practices have been established.

\subsubsection{Aquaculture and artisanal fishery}

The use of reservoirs for aquaculture is a common practice in many countries, with various restrictive regulations implemented to limit the environmental impact. In Brazil, aquaculture is permitted to be undertaken on $1 \%$ of the lake surface, but there is an ongoing discussion regarding the sustainability of this regulation [29]. In Itaparica reservoir, aquaculture systems with a production of $20,000 \mathrm{t} \mathrm{y}^{-1}$ have led to eutrophication of the reservoir, especially in the bays where there is a reduced water exchange [26]. Aquaculture systems are placed near the shoreline (short distance to travel for maintenance) in protected areas such as bays (less wind waves).

A small-scale artisanal fishery is a necessary part of the aquatic ecosystem that reduces fish biomass to an optimum level and avoids the over-ageing of the fish population. The fish biomass optimum is attained by a balanced predation effect in the trophic cascade of the predator-prey functional chain: High abundance of carnivorous fish $\rightarrow$ low abundance of planktivorous fish $\rightarrow$ increased 
development of zooplankton $\rightarrow$ reduced algae biomass due to zooplankton predation, and vice versa.

Our knowledge of the trophic cascade in tropical reservoirs is very limited, and the regulatory processes involved in tropical food webs are not well understood. Nevertheless, care should be taken to carefully manage fish populations and the optimization of fish yield and fishery effort. Additionally aquaculture within lakes or reservoirs should be prohibited, as is already the case in many countries, e.g. Chile, or at least limited to the carrying capacity of the reservoir [29].

\subsubsection{Sediment reuse}

Sediments deposited in a reservoir play a central role in carbon and nutrient cycling due to the processes of sediment respiration, absorption or desorption of ions, and redox-chemical reactions. In many reservoirs eutrophication is promoted and regulated by sediment based processes such as oxygen depletion, methane production and $\mathrm{P}$ release. The accumulation of sediment is encouraged by a decrease in the water depth, which reduces water stratification and creates more eutrophic conditions. Thus, all ESS linked to water quality are impacted, and sediment management is required to ensure an equilibrium of sediment accumulation and sediment abstraction for the long-term use of reservoirs. The technology used for sediment abstraction as part of a lake restoration plan is well developed in European countries, but the re-use of the sediments is challenging. Sand and gravel can be used for construction (e.g. roads), and fine sediments (silt, clay) can be used for soil amelioration, if the sediments are free of contaminants. Itaparica reservoir sediment has a low nutrient content, with a lack of nitrogen $(0.8$ $\mathrm{g} \mathrm{kg}^{-1} \mathrm{P}_{\text {total }}, 2.8 \mathrm{~g} \mathrm{~kg}^{-1} \mathrm{~N}_{\text {total }}$ and $28 \mathrm{~g} \mathrm{~kg}^{-1} \mathrm{C}_{\text {total }}$. However, the addition of silt and clay to soils increases the water storage capacity and ion exchange capacity, and improves soil quality parameters [30].

Sediment management can be realized with sediment abstraction (e.g. the use of sediment traps in the reservoir), the transportation by irrigation water and the distribution in agricultural areas. A sustainable sediment management has not yet been developed, but plant cultivation experiments (trees, tomatoes) at Itaparica reservoir have been successful.

\section{Conclusion}

Reservoirs have a central position in any water management, and clean water supply system, with the use of hydropower and protection of biodiversity being the main components of the associated environmental policy. Thus, an evaluation of ESS and their sustainable use is necessary, with the evaluation of human wellbeing and ecosystem goods still incomplete.

The main reason for the impact of reservoirs on nature and the damage to ESS is the mono-functional use of ESS and the corresponding reservoir management with regard to watershed use and management. Mono-functional use will maximize one service at the expense of others, with decreased human well-being in the current and future generations. 


\section{References}

[1] Selge, F. \& Gunkel, G., Water Reservoirs: Worldwide distribution, morphometic characteristics and thermal stratification processes. Sustainable Management of Water and Land in Semiarid Areas. ed. G. Gunkel, J.A. Silva, \& M.C. Sobral, Editora Universitária UFPE, Recife. ISBN 978-85-415-0259-7, pp. 15- 27, 2013.

[2] WCD, Dams and Development. A new Framework for decisions-making. ed. World Commission on Dams, Earthscan Publ. London, p. 322, 2000.

[3] Groot, R.S. de, Wilson, M.A., \& Boumans, R.M.J., A typology for the classification, description and valuation of ecosystem functions, goods and services. Ecological Economics, 41, pp. 393-408, 2002.

[4] Nahlik, A.M., Kentula, M.E., Fennessy, M.S. \& Landers, D.H. (2012) Where is the consensus? A proposed foundation for moving ecosystem service concepts into practice. Ecological Economics, 77, pp. 27-35, 2012.

[5] Haines-Young, R. \& Potschin, M., Common International Classification of Ecosystem Services (CICES): Consultation on Version 4, AugustDecember 2012. EEA Framework Contact No EEA/IEA/09/003, 2013.

[6] Boyd, J. \& Banzhaf, S., What are ecosystem services? The need for standardized environmental accounting unit. Ecological Economics, 63, pp. 616-626, 2007.

[7] CODEVASF, Serviço de assistência técnica e extensão rural destinado aos agricultores reassentados em decorrência da construção da Barragem de Itaparica - Lote 2: Borda do Lago. - Companhia de Desenvolvimento dos Vales do São Francisco e do Parnaíba. Relatório Final, Petrolina, 1998.

[8] Gunkel, G. \& Sobral, M., Reservoirs and River Basins Management: Exchange of Experience from Brazil, Portugal and Germany. Universitätsverlag der TU Berlin, ISBN: 978-3-7983-2056-7, p. 279, 2007.

[9] Gunkel G., Selge, F. \& Sobral, M.C., Re-oligotrophication of tropical water reservoirs as to minimize environmental impact. River Basin Management VII, ed. C.A. Brebbia, WIT Press Southampton, UK, ISBN 978-1-84564712-4, pp. 313-326, 2013.

[10] Gunkel, G., Silva, J.A. \& Sobral, M.C., Sustainable Management of Water and Land in Semiarid Areas. Editora Universitária UFPE, Recife. ISBN 978-85-415-0259-7, p. 295, 2013.

[11] Innovate, http://www.innovate.tu-berlin.de/, 2015.

[12] DEV, Deutsche Einheitsverfahren: Deutsche Einheitsverfahren zur Wasser, Abwasser- und Schlammuntersuchung. VCH, Weinheim, Loseblattsammlung, 2015.

[13] Barbosa, J.E.L., Medeiros, E.S.F. \& Brasil, J., Aquatic systems in semi-arid Brazil: limnology and management. Acta Limnologica Brasileira, 24(1), pp. 103-118, 2012.

[14] Maltby, E. \& Acreman, M.C., Ecosystem services of wetlands: pathfinder for a new paradigm. Hydro. Sciences Journal, 56, 8, pp. 1341-1359, 2011.

[15] Gunkel, G., Hydropower - A green energy? Tropical reservoirs and greenhouse gas emissions. Clean, 37, pp. 726-734, 2009. 
[16] CONAMA, Resolução No. 357, de 17 de Março de 2005.

[17] Portaria MS No. 2914 DE 12/12/2011 (Federal).

[18] OECD, Eutrophication of waters - monitoring, assessment and control. Organisation for Economic Co-operation and Development. Paris, p. 154, 1982.

[19] Salas, H.J. \& Martino, P., A simplified phosphorus trophic state model for warm-water tropical lakes. Wat. Res., 25, pp. 341-350, 1991.

[20] Huszar, V.L.M., Caraco, N.F., Roland, F. \& Cole, J., Nutrient-chlorophyll relationships in tropical-subtropical lakes: do temperate models fit? Biogeochemistry, 79, pp. 239-250, 2006.

[21] Phillips, G., Pietiläinen, O.P., Carvalho, L., Solimini, A., Solheim, A.L. \& Cardoso, A.C., Chlorophyll-nutrient relationships of different lake types using a large European dataset. Aquat Ecol., 42, pp. 213-226, 2008.

[22] NHMRC, NRMMC, Australian Drinking Water Guidelines Paper 6. National Water Quality Management Strategy. National Health and Medical Research Council, National Resource Management Ministerial Council, Commonwealth of Australia, Canberra, 2011.

[23] Rangel, L.M., Silva, L.H.S., Rosa, P., Roland, F. \& Huszar, V.L.M., Phytoplankton biomass is mainly controlled by hydrology and phosphorus concentrations in tropical reservoirs. Hydrobiologia, 693, pp. 13-28, 2012.

[24] Muhid, P. \& Burford, M.A. (2012) Assessing nutrient limitation in a subtropical reservoir. Inland Waters, 2, pp. 185-192, 2012.

[25] Turner, R.K., van den Bergh, J.C.J.M., Söderqvist, T., Barendregt, A. van der Straaten, J., Maltby, E. \& van Ierland, E.C., Ecological-economic analysis of wetlands: scientific integration for management and policy. Ecological Economics 35(1), pp. 7-23, 2010.

[26] Matta, E., Özgen, I., Hinkelmann, R., Cabral, J. \& Candeias, A.L., Simulation of wind-induced flow and transport in a Brazilian bay. ICHE 2014, Bundesanstalt für Wasserbau. ISBN 978-3-939230-32-8, pp. 233240, 2014.

[27] Velini, E.D., Corrêa, M.R., Tanaka, R.H., Bravin, L.F., Antuniassi, U.R. Carvalho, F.T. \& Galo, M.L.B.T., Avaliação operacional do controle mecânico de plantas aquáticas imersas no reservatório de Jupiá. Planta Daninha, Viçosa-MG, 23, pp. 277-285, 2005.

[28] Escobar, M.M., Voyevoda, M., Fühner, C. \& Zehnsdorf, A., Potential uses of Elodea nuttallii-harvested biomass. Energy, Sustainability and Society, 1(4), p. 8, 2011.

[29] Gunkel, G. Steemann, J. \& Sobral, M.C., Carrying capacity limits in net cage fish production in water reservoirs. Sustainable Management of Water and Land in Semiarid Areas. ed. G. Gunkel, G., J.A. Silva, \& M.C. Sobral, Editora Universitária UFPE, Recife. ISBN 978-85-415-0259-7, pp. 99-117, 2013.

[30] Walter, K., Gunkel, G. \& Gamboa, N., An assessment of sediment reuse for sediment management of Gallito Ciego Reservoir, Peru. Lakes \& Reservoirs: Research and Mangement 17, pp. 301-314, 2012. 